\begin{tabular}{|c|c|c|}
\hline \multirow[b]{2}{*}{ CEI I ENT } & Int.J.Curr.Microbiol.App.Sci (2021) 10(08): 325-328 & \\
\hline & $\begin{array}{l}\text { International Journal of Current Microbiology and Applied Sciences } \\
\text { ISSN: 2319-7706 Volume } \mathbf{1 0} \text { Number } 08 \mathbf{( 2 0 2 1 )} \\
\text { Journal homepage: } \underline{\text { http://www.ijcmas.com }}\end{array}$ & 98 \\
\hline PUBLISHERS & & www. ijcmas.com \\
\hline
\end{tabular}

Case Study https://doi.org/10.20546/ijcmas.2021.1008.038

\title{
Co-occurrence of Theileria orientalis and Babesia bigemina in a dairy cow - A case report
}

\author{
C. Mathivathani* and S. S. Das
}

Department of Veterinary Parasitology, Rajiv Gandhi Institute of Veterinary Education and Research (RIVER), Puducherry-9, India

*Corresponding author

Keywords

Theileria orientalis, Babesia bigemina

Article Info

\section{Accepted:}

15 July 2021

Available Online:

10 August 2021

\section{A B S T R A C T}

\section{Introduction}

Haemoparasitic infection in livestock in India is a serious concern for the farmers which causes anemia, debilitating conditions and even immunosuppression and also predisposes infected animal to various opportunistic infection (Nwoha et al., 2013). Haemoprotozoan infections are very common in cattle causing devastating losses to the livestock industry and pose a major threat to the dairy industry throughout the world. Theileriosis and babesiosis are two major haemoprotozoan diseases of crossbred cattle occurring in India transmitted by ixodid ticks. Tick fever or cattle fever (babesiosis) is economically the most important arthropodborne disease of cattle in India and in vast areas of Australia, Africa, South and Central America and the United States continuously under threat (Bock et al., 2004).

Babesiosis is a tick-transmitted disease caused by protozoan of the genus Babesia and it is characterized by haemolytic anemia and fever, with occasional hemoglobinuria and death (Nwoha et al., 2013). It is a disease with a world-wide distribution affecting many species of mammals with a major impact on cattle and man (Bock et al., 2004, Zintl et al., 2003). Bovine babesiosis has a huge economic impact due to loss of milk production of infected animals and death.

Theileria spp. are obligate intracellular protozoan parasites of the order Piroplasmida, 
family Theileriidae. Theileriosis in cattle is characterized by pyrexia, progressive anemia, swelling of lymph nodes and respiratory distress.

The disease is now reported more frequently and the incidence of theileriosis in India over the last four decades gives a varied range from $3.5-15 \%$ in cattle in field and farm conditions.

\section{Materials and Methods}

A dull, anorectic moderately tick infested 4 year old crossbred Jersey cow from Puducherry with bruxism, swollen prescapular lymph node, pyrexia $\left(105.1^{\circ} \mathrm{F}\right)$ and open mouth breathing was noticed. The blood smear was prepared from ear vein and stained with Leishman's stain to screen for the presence of blood protozoan parasite.

\section{Results and Discussion}

Upon examination of blood smear, the red blood cells were found mostly anaemic few with Rouleax formation. Following vigorous searching the presence of piroplasms of Theileria sp. and Babesia sp. were recorded. (Picture 1\& 2) The parasites were confirmed as Theileria orientalis and Babesia bigemina as per description of Soulsby (1982).

The most predominant features of T.orientalis was rod shaped structure in the erythrocytes piroplasm stage and for Babesia pear shaped form was predominant with acute angle in apex of pear shaped form apposing each other.

Blood smear was anaemic in appearance with centrally vaculated RBCs, the animal was dull depressed with reduced milk yield.

Tick borne haemoparasitic diseases have a global distribution, stretching from the polar circle to the equator because of wide host range of ticks and its ability to withheld environmental stress and high fecundity. Haemoparasitic infection especially Babesia and Theileria may lead to lower milk production or even death in acute phase.

The incidence of mixed infection of haemoprotozoan parasites in cow had been reported worldwide. Mixed infection of Theileria and Babesia in Puducherry is scanty and finding of this result may be the indicative of multiple disease transmitting ticks present in and around Puducherry since Puducherry open grazing practice is not very uncommon therefore enzootic stability might help to sustain.

The present blood smear is an additional finding with an open mouth breathing syndrome. The presence of tick infestation reveals the carrier state of cattle population in Puducherry as well as carrier state of two host ticks.

This finding revealed the fact that tick control procedures should be taken into account on priority basis. Conventional microscopic detection methods are still the cheapest and fastest method for identification of blood protozoan parasites in spite of having limited sensitivity and specificity in comparison to immunological and molecular methods.

Nowadays added to the production costs, the high cost of tick control, disease detection, prevention and treatment cost etc., has been added (Perez de Leon et al., 2010).

Moreover an indirect and underestimated cost of the disease is related with the refusal of cattle farmers in endemic areas to improve the production of milk in their herds by introducing milk-producing, pure-breed animals, most of them from tick-free areas, because they will present an acute form of the disease and many will die in the following weeks to their arrival. 


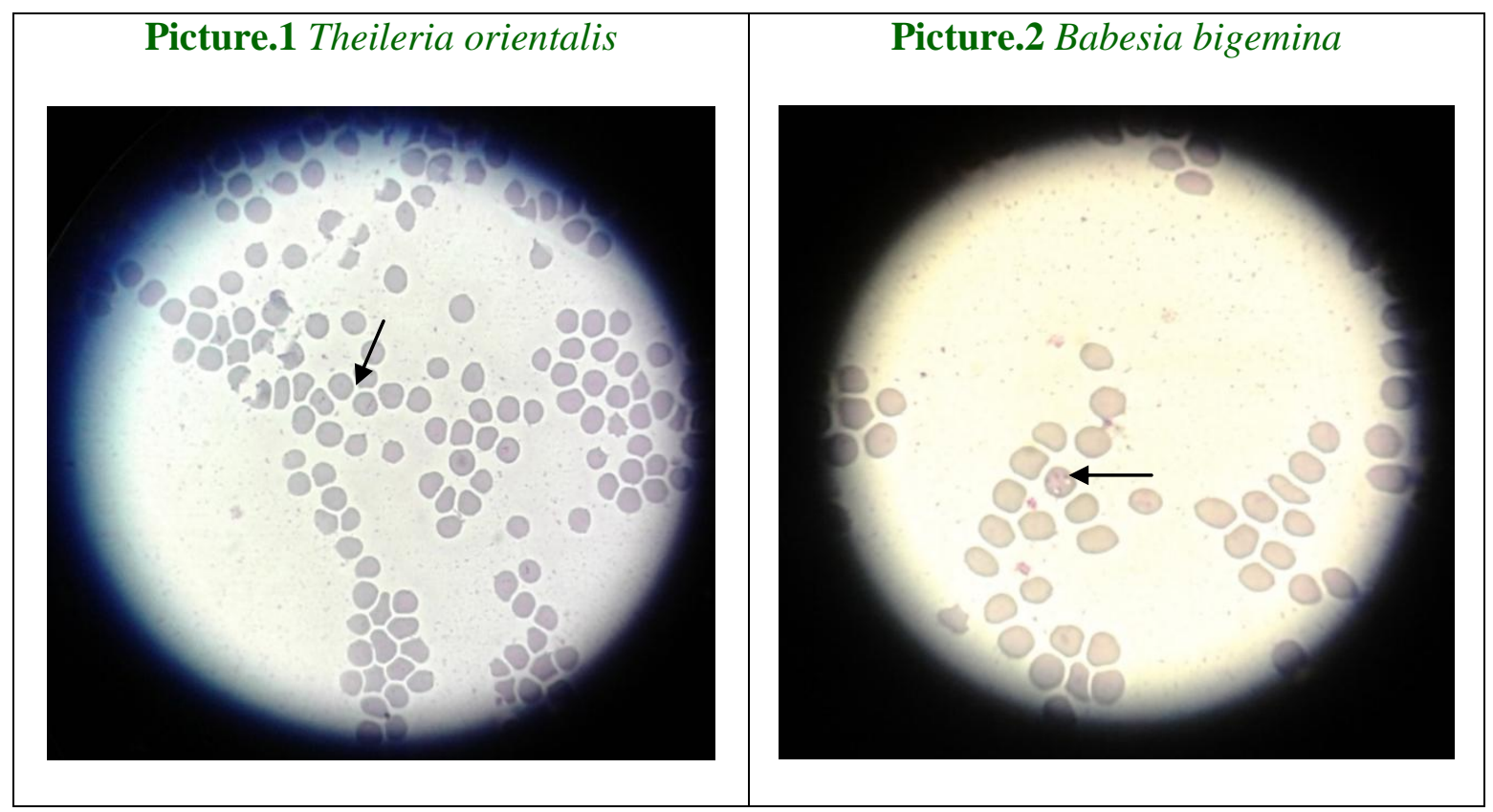

The consequence is that the quality of cattle in endemic areas remains low, therefore impeding the development of the cattle industry and the wellbeing of producers and their families (Mosqueda et al., 2004).

\section{Acknowledgments}

The authors are thankful to Dean, Rajiv Gandhi college of Veterinary Education and Research for providing the necessary facility and support.

\section{References}

Bock R, Jackson L., De Vos A. and Jorgensen W. 2004, Babesiosis of cattle Parasitology 129 (S1), 247-269

Mosqueda J, Falcon A, Antonio Alvarez J, Alberto Ramos J, Oropeza-Hernandez L F, Figueroa J V. 2004 Babesia bigemina sexual stages are induced in vitro and are specifically recognized by antibodies in the midgut of infected Boophilus microplus ticks. International Journal for Parasitology 34(11) 1229-1236.

Nwoha R I O, Onyeabor A, Igwe K C, Daniel
G, Onuekwusi G C O and Okah U Prevalence of Haemoparasites in Livestock in Ikwuano Local Government Area of Abia State Journal of Fisheries \& Livestock Production September 1, 2013 vol 2 issue $1 \mathrm{~J}$ Fisheries Livest Prod

Perez de Leon A A, Strickman D A, Knowles D P, Fish D, Thacker E, de la Fuente J, Krause P J, Wikel S K, Miller R S, Wagner G G, Almazan C, Hillman R, Messenger M T, Ugstad P O, Duhaime R A, Teel P D, Ortega-Santos A, Hewitt D G, Bowers E J, Bent S J, Cochran M H, McElwain T F, Scoles G A, Suarez C E, Davey R, Howell Freeman J M, Lohmeyer K, Li A Y, Guerrero F D, Kammlah D M, Phillips P, Pound J M. One Health approach to identify research needs in bovine and human babesioses: workshop report. Parasites \& Vectors. 2010;3(1):36.

Soulsby E. J. L. Helminths, Arthropods and Protozoa of Domesticated animals

Soulsby E J L. Helminths, Arthropods and Protozoa of Domesticated Animals. (7th Ed.). ELBS Balliere, Tindall, London, 1982, pg no. 
Zintl A, Mulcahy G, Skerrett H E, Taylor S M, Gray J S. Babesia divergens, a

zoonotic importance. Clinical bovine blood parasite of veterinary and microbiology reviews. 2003;16(4):622-636.

\section{How to cite this article:}

Mathivathani, C. and Das, S. S. 2021. Co-occurrence of Theileria orientalis and Babesia bigemina in a dairy cow - A case report. Int.J.Curr.Microbiol.App.Sci. 10(08): 325-328. doi: https://doi.org/10.20546/ijcmas.2021.1008.038 